CDI

25,1

32

Received 30 January 2018

Revised 22 May 2018

22 November 2018

20 March 2019

10 April 2019

Accepted 15 April 2019

\section{Refugees' inclusion at work: a qualitative cross-level analysis}

\author{
Lena Knappert \\ Department of Human Resource Studies, \\ Tilburg University, Tilburg, The Netherlands \\ Hans van Dijk \\ Department of Organization Studies, \\ Tilburg University, Tilburg, The Netherlands, and \\ Veerle Ross \\ KPMG Holding NV, Amsterdam, The Netherlands
}

\begin{abstract}
Purpose - Refugees' inclusion at work is critical for the individual, for employers and for the receiving societies. Yet, refugees are often disadvantaged in working life or are being excluded from the labor market altogether. The purpose of this paper is to examine barriers and facilitators to refugees' inclusion at work at the individual, organizational and country level, and pay particular attention to how the three levels relate to each other in shaping inclusion and exclusion of refugees at work.

Design/methodology/approach - The authors conducted 18 interviews with employed refugees, employers and experts from governmental and non-governmental institutions in the Netherlands.

Findings - Based on the theoretical structure, 13 themes emerged from the interview material -5 themes at the individual level, 4 at the organizational level and 4 at the country level. The authors also found indicators for an interplay of barriers and facilitators across levels.

Research limitations/implications - This is a small study conducted in the Netherlands, providing several starting points for future research.

Practical implications - The authors provide recommendations for refugees, employers and policy makers aimed at addressing barriers and leveraging facilitators of refugees' inclusion at work.

Originality/value - The organizational level, which diversity research has shown to affect minority group members' inclusion at work, is rarely taken into account in refugee research. Based on the cross-level analysis, the authors identify patterns of interplay between the three levels and provide a relational framework of refugees' inclusion at work.
\end{abstract}

Keywords Discrimination, Migrant workers, Equal opportunities

Paper type Research paper

The global community is currently witnessing the historically highest number of people fleeing war and persecution (UNHCR, 2018). For many of these refugees, Europe is the final destination, which makes the integration of several million people from various backgrounds a crucial task for the European Union (Betts and Collier, 2015; Eurostat, 2017; The Economist, 2015). Finding relevant work has been shown to be of particular importance for the integration of refugees, given that employment directly affects their financial independence (e.g. de Vroome and van Tubergen, 2010), well-being and health (e.g. Ager and Strang, 2008), acculturation (e.g. García-Ramírez et al., 2011), and their acceptance among the receiving societies (e.g. Markaki and Longhi, 2013). Yet, we also know that refugees hold a disadvantaged labor market position that keeps them in occupations

(C) Lena Knappert, Hans van Dijk and Veerle Ross. Published by Emerald Publishing Limited. This article is published under the Creative Commons Attribution (CC BY 4.0) licence. Anyone may reproduce, distribute, translate and create derivative works of this article (for both commercial and non-commercial purposes), subject to full attribution to the original publication and authors. The full terms of this licence may be seen at http://creativecommons.org/licences/by/4.0/legalcode
Career Development International Vol. 25 No. 1,2020 pp. $32-48$ Emerald Publishing Limited $1362-0436$ DOI 10.1108/CDI-01-2018-0021 
with a lower status than their actual profession, or out of jobs altogether (e.g. Ager and Strang, 2008; Baranik et al., 2017; Cheung and Phillimore, 2014; Hooijer and Picot, 2015).

Most explanations for the limited access of refugees to work in host societies focus on the individual level (experiences of refugees) by applying social and human capital theory (e.g. de Vroome and van Tubergen, 2010; Hartog and Zorlu, 2009), or on the country level by focusing on country-specific policies and programs (e.g. Bleijenbergh et al., 2014). In contrast, the organizational level and interrelations among the three levels, which diversity research has shown to affect minority group members' inclusion at work (Syed and Özbilgin, 2009; Syed and Pio, 2010), are rarely taken into account. This is particularly surprising in light of employers' interest in this particular group of potential employees to fill labor and skills shortages (The Economist, 2015; van Wassenhove, 2015); the "significant thematic and logical convergences" (de Jong, 2016, p. 431) shared by research on diversity management and migration studies; and the need for a multi-level understanding of effective management of employees' inclusion (Syed and Özbilgin, 2009). Hence, the leading research questions of this study are as follows:

$R Q 1$. What are the individual, organizational and national facilitators and barriers for refugees' inclusion in Dutch workplaces?

$R Q 2$. How do these facilitators and barriers operate across the three levels?

In answering these research questions, we contextualize refugees' inclusion by building on the relational framework of diversity management by Syed and Özbilgin (2009), differentiating the individual, organizational and country level as well as their interrelations. To explore this complex interplay, we applied a qualitative approach and analyzed semi-structured interviews with eight refugees, four employers and six experts from governmental and non-governmental organizations (NGOs).

Our study offers several contributions. First, by applying Syed and Özbilgin's (2009) relational framework, this study facilitates a more encompassing understanding of refugees' inclusion than single-level conceptualizations of diversity and inclusion. Specifically, we identify individual-, organizational- and country-level influences as well as patterns of their interrelations across levels, based on which we develop a relational framework of refugees' inclusion at work. As an important part of this analysis, we shed light on employers' perspectives and the largely ignored organizational level of refugees' inclusion at work. As a result, we point out critical themes that have not been identified previously and argue that refugee status should be considered as a distinct type of diversity (like gender, age, disability, etc.). Next, by focusing on the Netherlands, this paper follows previous calls to provide country-specific perspectives on diversity management in general (Farndale et al., 2015; Klarsfeld et al., 2016; Nishii and Özbilgin, 2007) and, more specifically, on the integration of refugees in host society's organizations (e.g. Knappert et al., 2018; Pedersen, 2012). Finally, our findings provide some specific suggestions for policy makers, employers and refugees to facilitate refugees' inclusion at work.

\section{A relational framework of refugees' inclusion}

Our theoretical starting point is the concept of inclusion as defined by Shore et al. (2011, p. 1265), who describe it as "the degree to which an employee perceives that he or she is an esteemed member of the work group through experiencing treatment that satisfies his or her needs for belongingness and uniqueness." Following this conceptualization, refugees' inclusion is considered an individual experience that plays an important role for outcomes such as refugees' careers, well-being and performance. We contextualize refugees' inclusion by drawing on Syed and Özbilgin's (2009) relational framework of diversity management. Applying the perspective of sociological realism, the authors developed a multi-layered

\section{Refugees' inclusion at work}


CDI

25,1

conceptualization that considers individual (e.g. individual experiences, opportunities and agency), organizational (e.g. organizational processes and approaches to diversity) and national (e.g. a society's beliefs and values, laws, education) levels of the phenomenon. Further, the framework specifically acknowledges that these levels do not operate in isolation but relate to each other. Hence, we argue that an understanding of refugees' inclusion at work necessitates an examination of influences not only at the individual level, but also at the organizational and the country level, as well as the interplay among these three levels.

Analyzing the individual level, we focus on an individual's "unique resources and agency that equip her/him to respond to the various issues and challenges" (Syed and Özbilgin, 2009, p. 2443) at work. Indeed, prior research has shown that various factors at the individual level, including language proficiency, work experience, gender and contact with host country nationals, affect refugees' access to and inclusion at work (e.g. de Vroome and van Tubergen, 2010; Knappert et al., 2018). Regarding the organizational level, previous research has repeatedly shown how organizational policies and approaches toward diversity shape diversity and inclusion (e.g. Cox, 1994; Dobbin and Kalev, 2016; Ely and Thomas, 2001; Nishii, 2013). In fact, Shore et al. (2011) frame the experience of inclusion as a consequence of organizational antecedents, such as diversity management practices. We therefore expect organizational-level factors to be crucial in shaping refugees' perceptions of inclusion at work, but to date there is very limited research on refugee inclusion at work that specifically looked at organizational influences. With respect to the country level, we know that national cultures and institutional structures such as a country's legislative framework regarding equal opportunity are important drivers of diversity and inclusion in organizations (Farndale et al., 2015; Klarsfeld et al., 2014). For instance, Peretz et al. (2015) found cultural practices to moderate the relationship between organizational diversity programs and employee absenteeism and turnover. Other examples show how political changes and cutbacks in subventions for diversity programs at the national level affect organizational practices and eventually the inclusion or exclusion of underrepresented groups (Bleijenbergh et al., 2014). Given that countries tend to have strict regulations regarding refugees and work, we expect that there are also national factors that shape refugees' perceptions of inclusion at work. Figure 1 summarizes the conceptual starting point of this study.

Figure 1.

Conceptual starting point of this study

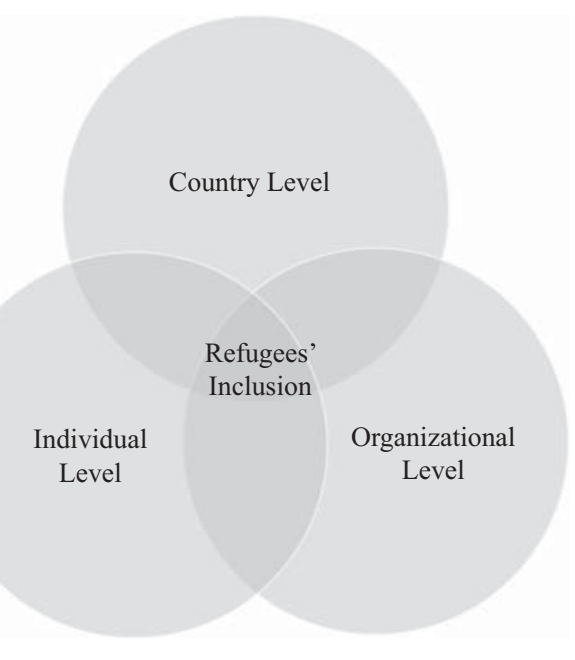


Despite Syed and Özbilgin's (2009) call for cross-level research on inclusion, there have been only limited investigations on the relationships among the individual, organizational and country level, even less so with regard to refugees' inclusion (for a recent exception that looked at how national- and organizational-level factors shape gender differences in refugees' perceived inclusion at work in Turkey, see Knappert et al., 2018). In this study, we therefore focus on how cross-level relationships among factors shape refugees' inclusion.

\section{Refugees' inclusion in the Netherlands}

The Netherlands has a history of being a popular destination for refugees, but in the last decade has become somewhat less welcoming (MIPEX, 2018). The financial crisis, increased unemployment and more conservative governments have caused the Netherlands to be more reserved toward refugees. Following a sudden increase in asylum applications due to the Syrian war, these developments also resulted in the EU-Turkey deal in which the EU promised Turkey money in exchange for preventing refugees from coming to Europe (The Economist, 2016). In fact, in 2015 (before the deal), a total number of 43,093 people (including 18,766 Syrians) requested asylum in the Netherlands. In 2017 (after the deal), only 14,716 refugees requested asylum (of which 2,202 were Syrians) (VluchtelingenWerk, 2018).

Refugees who request asylum in the Netherlands are first obliged to stay in a reception center. Their stay in such a center can last for months or even years, during which they remain in relative isolation from the wider Dutch society and in the first six months are not allowed to engage in paid work. After these six months, if they are still in the asylum request procedure, paid work is only allowed under specific circumstances (e.g. the employer must provide a permit; asylum seekers can only keep 25 percent of their income to a maximum of $€ 185$ per month). During the asylum request procedure, refugees receive up to $€ 232$ per month from the Dutch Government for food, clothing and other expenses (Rijksoverheid, 2018a). Once refugees are granted asylum, they are obliged to follow an integration course (which takes about $600 \mathrm{~h}$ ) that they need to pass within three years. The majority of this integration course focuses on learning the Dutch language and culture, but there is also a part that is aimed at preparing the refugees for the Dutch labor market. However, even 10 years after being granted asylum only one-third of refugees between 18 and 64 years old have paid work for more than $30 \mathrm{~h}$ a week in the Netherlands (Engbersen, 2015).

To improve the position of refugees in the labor market, the Dutch Government has implemented several programs (e.g. labor market guidance for refugees; integrated language and schooling trajectories; and tailored support and coaching in finding work) and provided a number of subsidies for employers aimed at stimulating refugee employment (SER, 2018). Since these programs have been in place, employers have tended to be more open to employing refugees. Their motivation to do so ranges from intrinsically wanting to contribute to refugee integration to the extrinsic motivation of hoping that refugees can fill long-term vacancies (Razenberg and de Gruijter, 2017). These developments, however, have not yet led to a significant improvement in the position of refugees in the labor market. From the employers' perspective, difficulties in approaching refugees and a perceived mismatch of job requirements and refugees' qualifications are important reasons why many employers are not recruiting refugees (SER, 2018). The Dutch Government, therefore, assigned an additional EURO 10m until 2020 to implement more measures to enhance refugees' participation in the Dutch labor market (Rijksoverheid, 2018b).

Taken together, the question of which factors facilitate and hinder the labor market participation of refugees in the Netherlands, and in particular the role of employers therein, is a timely one. In the following, we address this question by examining the barriers and facilitators to refugee inclusion at work in the Netherlands.

\section{Refugees' inclusion at work}


CDI

25,1

36

\section{Methods}

This study was designed to analyze the individual, organizational and national facilitators and barriers for refugees' inclusion, and their interrelations across levels. To allow for theoretical guidance as well as theoretical saturation while investigating this complex interplay, we conducted 18 semi-structured, face-to-face interviews with important stakeholders, which we analyzed using qualitative content analysis (Gläser and Laudel, 2013).

\section{Sample}

To be able to explore the three levels and their interrelations, the selection of interview partners involved actors representing the individual level (i.e. the refugees themselves), the organizational level (i.e. employers and an employment agency) and the country level (i.e. governmental and NGO representatives). The interviewed refugees $(n=8$, three female, five male, aged between 24 and 44) were all employed and had the legal right to work in the Netherlands. Their countries of origin were Armenia, Eritrea, Senegal and Syria, and their educational level varied from high school to university level (see Table I).

The employers' perspective was included in our study by interviewing managers $(n=4)$ from a consultancy company, an employment agency and a housing corporation. Finally, the sample of refugee experts consisted of people who were working for local governmental organizations $(n=2)$ and NGOs focusing on refugee matters $(n=4)$ (see Table II).

\section{Data collection and analysis}

The interviews took place in 2016, were conducted by all members of the research team and lasted between 60 and $120 \mathrm{~min}$. In the beginning of each interview, we read through the participant consent form to assure all interview participants confidentiality and anonymity. Depending on the preference of the respondent, interviews were conducted in Dutch or English. The interviews were transcribed verbatim, and Dutch transcripts were translated to English to ensure that all members of the international research team could understand and analyze them (Zikic et al., 2010). Two parallel semi-structured interview guidelines were used that were taken from a larger research project. One guideline of 42 questions was specified for refugees and the other one with 32 questions was specified for employers and experts.

\begin{tabular}{|c|c|c|c|c|c|c|}
\hline $\begin{array}{l}\text { Interview } \\
\text { participant key }\end{array}$ & Age & Gender & $\begin{array}{l}\text { Country } \\
\text { of origin }\end{array}$ & $\begin{array}{l}\text { Years living in the } \\
\text { Netherlands }\end{array}$ & Highest educational level & $\begin{array}{l}\text { Current } \\
\text { position }\end{array}$ \\
\hline Refugee 1 & 24 & M & Senegal & 3 & $\begin{array}{l}\text { High school in country of } \\
\text { origin }\end{array}$ & $\begin{array}{l}\text { Warehouse } \\
\text { employee }\end{array}$ \\
\hline Refugee 2 & 32 & $\mathrm{~F}$ & Armenia & 17 & $\begin{array}{l}\text { University of Applied Sciences } \\
\text { in the Netherlands }\end{array}$ & $\begin{array}{l}\text { Legal } \\
\text { assistant }\end{array}$ \\
\hline Refugee 3 & 44 & M & Syria & 2 & $\begin{array}{l}\text { University of Applied Sciences } \\
\text { in country of origin }\end{array}$ & Interpreter \\
\hline Refugee 4 & 24 & $\mathrm{~F}$ & Armenia & 17 & $\begin{array}{l}\text { University level in the } \\
\text { Netherlands }\end{array}$ & $\begin{array}{l}\text { Production } \\
\text { employee }\end{array}$ \\
\hline Refugee 5 & 26 & M & Syria & 2 & $\begin{array}{l}\text { High school in country of } \\
\text { origin }\end{array}$ & Hairdresser \\
\hline Refugee 6 & 31 & M & Syria & 1,5 & $\begin{array}{l}\text { University level in country of } \\
\text { origin }\end{array}$ & $\begin{array}{l}\text { All-round } \\
\text { employee }\end{array}$ \\
\hline Refugee 7 & 34 & M & Syria & 2 & $\begin{array}{l}\text { University level in country of } \\
\text { origin }\end{array}$ & Interpreter \\
\hline Refugee 8 & 31 & $\mathrm{~F}$ & Eritrea & 5 & $\begin{array}{l}\text { University level in the } \\
\text { Netherlands }\end{array}$ & $\begin{array}{l}\text { Accountant } \\
\text { associate }\end{array}$ \\
\hline
\end{tabular}

Table I.

Refugee sample 


\begin{tabular}{|c|c|c|c|c|}
\hline $\begin{array}{l}\text { Interview } \\
\text { participant } \\
\text { key }\end{array}$ & Gender & $\begin{array}{l}\text { Type of } \\
\text { organization }\end{array}$ & Current position & $\begin{array}{l}\text { Retugees } \\
\text { inclusion } \\
\text { at work }\end{array}$ \\
\hline Employer 1 & $\mathrm{~F}$ & Consultancy company & Program manager refugee talents & \\
\hline Employer 2 & $\mathrm{~F}$ & Consultancy company & CSR manager & \\
\hline Employer 3 & $\mathrm{~F}$ & Employment agency & Program manager social development and inclusivity & \\
\hline Employer 4 & $\mathrm{M}$ & Social housing organization & Manager & 37 \\
\hline Expert 1 & $\mathrm{~F}$ & Local government X & Reintegration coach, women & \\
\hline Expert 2 & & Local government X & Account manager & \\
\hline Expert 3 & $\mathrm{~F}$ & Local government Y & Policy employee economics and labor market & \\
\hline Expert 4 & M & Local government $Z$ & Advisor refugees & Table II. \\
\hline Expert 5 & M & NGO A & Consultant job support & Sample of refugee \\
\hline Expert 6 & $\mathrm{M}$ & NGO B & Project manager & experts and employer \\
\hline
\end{tabular}

Guidelines covered questions regarding the respondents' personal background, refugees' perception of their current work situation, diversity and inclusion practices in the current organization, and the role of the Dutch context.

Data were coded using the software NVivo. In following the principles of qualitative content analysis (Gläser and Laudel, 2013), our analysis was guided by theoretical concepts (i.e. we coded barriers and facilitators on the individual, organizational and country level) and fed by the extracted contents from the interviews that we summarized and rephrased in an analytic language (i.e. codes). In several intense discussions with the research team, we clarified ambiguous interview sections, readjusted codes and explored possible patterns. After this first step of data reduction, we engaged in the recursive process of thematic analysis by collating codes into themes that we reviewed several times and eventually defined and named (Braun and Clarke, 2006).

\section{Results}

Through our data analysis, we identified 13 themes -5 themes at the individual level, 4 at the organizational level and 4 at the country level. Mirroring the structure of our conceptual starting point (see Figure 1), Figure 2 displays all themes along the two dimensions that are relevant to our research question: individual, organizational and country level; and barrier vs facilitator of refugees' inclusion (indicated by - and + , respectively). Further, we found patterns regarding interrelations among the individual, organizational and country levels that are also shown in Figure 2. We will present patterns and three prominent examples of this interplay at the end of this section.

\section{Barriers and facilitators at the individual level}

The only barrier to refugees' inclusion at the individual level that was repeatedly mentioned by our participants was refugees' human capital, i.e., their qualifications and skills. We found that refugees with more limited education (with high school-level degrees) expressed contentment with their jobs, whereas higher educated refugees (i.e. those with more human capital) expressed discontent about underemployment, that is, they did not feel appreciated or included due to a mismatch between their qualification and job opportunities offered to them (Krahn et al., 2000).

Conversely, and mirroring previous research (e.g. Ager and Strang, 2008; de Vroome and van Tubergen, 2010; Portes, 2000; Yakushko et al., 2008), several respondents emphasized the importance of refugees' proficiency in the Dutch language and social capital (i.e. resourceful social ties). Refugees often have limited proficiency in Dutch when fleeing to 


\section{CDI}

25,1

\section{8}

Figure 2.

A relational

framework of refugees'

inclusion at work

\section{COUNTRY LEVEL}

- Economic crisis

- Legislative hurdles

+ Memory of host country's

migration history

+ Sympathetic media coverage
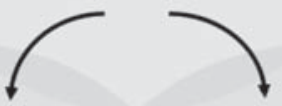

ORGANIZATIONAL

LEVEL

- Human capital

+ Host country language proficiency

+ Social capital

+ Volunteering

+ Motivation
- Strict language requirements

Refugees' Inclusion

- Stereotypes and biased procedures

+ Corporate Social Responsibility

+ Strategic use of "refugee" label

the Netherlands. However, language proficiency has been described as a major facilitator by both refugees and employers. As one manager put it:

Dutch is very important for us. We are a global organization, but we do have a lot of Dutch clients. (Employer 1)

Further, refugees confirmed the relevance of social capital. Especially in the beginning when newcomers lack a local network, which was highlighted as particularly burdensome during job search. As one of the refugees made clear:

At first they were telling me some of the stuff like I was overqualified. But then I was thinking I am underqualified. And until I could find the right person the only option that as an individual, if you try to find a job individually, you try only on internet [...] but it is about how to find the right person. The right connection to whom to hand your CV. So that was really tough for me. (Refugee 8)

To familiarize themselves with the Dutch labor market, build networks with host country nationals and learn the language, some respondents described volunteering as a promising way forward:

That they [refugees] will find as fast as they can a volunteer job, despite setbacks and hearing 'no' a lot. It is very important to volunteer at a soccer club, get yourself into the society and not stay at home too much. (Expert 5)

The role that volunteering plays in supporting employees' attempts to enter the labor market has not been fully investigated (Tomlinson, 2010). However, hoping to eventually 
find employment, volunteering seems to be perceived as "a foot in the door" by some refugees, and most experts supported this perception (see also SER, 2018). Undoubtedly, volunteering with the hopes of finding paid employment requires not only financial means but also sustained determination and high motivation. In fact, refugees' high motivation to work and to participate was pointed out by several respondents as one of their assets:

The best strength that they [refugees] have shown is that they can cross all borders. So they are motivated and will go the extra mile. (Expert 6)

Interestingly, some of the interviewed refugees were very much aware of how their motivation is perceived by the locals:

People $[\ldots]$ see how motivated refugees are. What kind of obstacles they overcome. How positive they are, they are persistent. (Refugee 2)

The issue of refugees' high motivation is not yet well understood in the literature, which is surprising given the importance of agency for refugees' own creation of opportunities (Zanoni and Janssens, 2007).

\section{Barriers and facilitators at the organizational level}

Regarding the organizational level, our respondents largely confirmed earlier findings that strict language requirements as part of job descriptions are major hurdles for refugees to even be considered for a vacancy. Further, stereotypes shared by organizational members, in particular by recruiters (Derous et al., 2012), and biased procedures create barriers for inclusion:

Companies still have a lot of incomprehension against certain groups. Ignorance, what we do not know, we fear. (Expert 2)

On the employers' side, an example for biased procedures was provided by a manager in an employment agency:

[...] our customers expect us to deliver the best talents. That is why they hire us, because they cannot find the candidates themselves, so sometimes the refugee is indeed the best person for the job, because of his qualifications and his skills. But often he is not, because what we see is that they have a gap on their resume of mostly three years. So then there is a great chance that the employer says: I have someone else with no gap on his resume and I will hire that person. So that is also something we encounter as an obstacle. (Employer 3)

Importantly, stereotypes and biased procedures have been observed in both private and public organizations, which creates a particularly strong barrier for refugees' inclusion. As one expert shared with us:

What we see is that in some local governments, if they know you are a refugee you will be on the bottom of the priority list. (Expert 6)

Conversely, several respondents suggested that, in light of the recent influx of refugees, organizations in the Netherlands are taking their responsibility as employers and relevant stakeholders of society increasingly seriously. In the context of corporate social responsibility (CSR), most organizations have implemented ethical and social standards and developed programs to meet these standards (Carroll, 1999; Lindgreen and Swaen, 2010). Several employers indicated that they have specific CSR programs that target refugees' inclusion, for example, by collaborating with NGOs and by providing internships or mentoring for refugees. One employer pointed out:

I think at the moment we are not recruiting a lot of people, so we have a sort of a slowdown in the recruitment. But we do hire refugees still [...] so we really put extra focus on hiring refugees [...]

Refugees' inclusion at work 
CDI

25,1

We have now 15 refugees working with [company]. That is top priority for us, to recruit them, but also make them successful within [company]. (Employer 2)

A particularly interesting finding is the strategic use of the "refugee" label at the organizational level. For example, one of the employers explained that they applied vs removed the "refugee" label depending on the human resource practice in question. Specifically, because the company was interested in hiring refugees as part of their CSR efforts, they recruited specifically "refugee" candidates. However, once identified as a candidate for a position, the "refugee" label was purposefully removed in order to ensure equality among candidates:

We do make the distinction while recruiting, because you need to use different channels, but once they are in the recruitment process they are normal employees. They are not refugees. (Employer 2)

Similarly, a project leader from a NGO explained how the organization applied the "refugee" label as a facilitator for the NGO's work and to guide other stakeholders' attention:

In the project we used and misused the word "refugee", because sometimes you want to have attention and then we are talking about refugees and sometimes you do not want to have too much attention and then you say "people" or "talented people". (Expert 6)

These examples show how the "refugee" label can help or hinder refugees' inclusion. The quotes also make clear that many actors, including refugees themselves, are very aware of this and use the label depending on their purpose. One refugee told us:

I also deleted my nationality from my CV. [...] I deleted it on purpose. Only organization X [refugee organization] advised me to leave it on my CV, but other people like the local government told me: No, leave it out, it has no advantage. (Refugee)

\section{Barriers and facilitators at the country level}

While "economists tend to see a large influx of refugees not as an obligation or a threat - but as an opportunity" (Portes, 2018), in the wake of a global economic crisis, public opinion tends to highlight deep-rooted fears that refugees will take away jobs from host country workers. Following the general public opinion, we heard several statements about how the economic situation in the Netherlands at the time of data collection limited job opportunities for refugees. Also, refugees themselves were convinced that:

Dutch people also do not have jobs, there are no vacancies. The economic situation now is a general problem for everyone. (Refugee 6)

Further, we found the legislative hurdles that accompany refugees from the moment they officially arrive in a host country to create several obstacles for their employment and inclusion. For example, several refugees told us that the qualifications they earned in their home countries are not acknowledged in the Netherlands, often leading them into underemployment (Baranik et al., 2017; Krahn et al., 2000):

In Syria I was a lawyer, but here my diploma does not work. If I want to be a lawyer again I have to go study maybe one or two years. (Refugee 7)

Such processes that are necessary for refugees to establish their legal and professional status take time. Often this is perceived as time that passes all too slowly, especially by refugees themselves but also by the employers:

What we see is that a lot of people in The Netherlands could work with the skills we need but they are not yet allowed to work. So it is not specifically what hinders our company, but what hinders asylum seekers, to start working immediately. [...] There are a lot of rules and I think that is not very helpful. I think we are in a country with a lot of legislation and everything. Procedures and rules and if you are not familiar with that, it can be difficult. (Employer 2) 
Meanwhile, refugees are subject to relocations that seem to work against their integration into society and their inclusion at work:

These people are randomly located to a [asylum] center, without knowing which government they will end up with in the end. If they are in the center in Tilburg [South of The Netherlands], it can be possible that they are relocated to Groningen [North of The Netherlands]. [...] The people that are staying in the center already live there, know the neighborhood and know the city. And then when they get a permit they need to move to a completely different city. But from the moment they enter the country they already start integrating. (Expert 1)

Next to these hindrances, our participants also mentioned some national influences that they described as rather helpful for refugees' inclusion, for example, the role of Dutch national's memory of their country's migration history:

We are basing things on the integration we are used to, from our history. The belief that if every individual can be him or herself, it will create the best society. This is the ongoing discussion about integration and assimilation. We do it like we did it in the past and it will be all right. (Expert 4)

The same respondent also highlighted how the memory of refugees in the context of the Second World War might influence refugees' inclusion today:

A part of the society sees refugees as something to take care of as an extension of the Second World War - that they should be hosted, that we have a humanitarian obligation. I think that the memory of the Second World War could help. (Expert 4)

This sequence of Dutch history was also reflected on by one of the interviewed refugees:

Sometimes maybe people from Holland, they still remember the Second World War. So this makes it easier to understand our situation now. Because we have the same now. (Refugee 6)

Finally, most of our respondents described the Dutch media's growing interest and often sympathetic coverage of the refugees' situation as a facilitator for refugees' inclusion at work. For instance, a project manager from a refugee organization mentioned that, with the increase of media attention, the Dutch society's awareness regarding refugees is increasing too:

Unfortunately, there was a picture of the little boy on the beach in Greece [the picture showed the dead body of a Syrian boy who did not survive the boat trip across the Mediterranean] that helped a lot to support refugees towards work. A lot of organizations, companies, individuals are connecting with our organization to help refugees. (Expert 6)

\section{Interrelations between the levels}

In line with the relational framework by Syed and Özbilgin (2009), we focus not only on the analysis of barriers and facilitators on the individual, organizational and country level, respectively, but pay particular attention to the interplay between the three levels. This additional step also allowed us to observe patterns of interplay. That is, the general direction of influence seems to be top-down, and barriers and facilitators at the country level tend to shape refugees' inclusion through barriers and facilitators at lower-order levels. In this subsection, we present three examples that capture these patterns.

The first example describes the interplay between the country level and the organizational level, with positive consequences for refugees' inclusion. Our participants reported that the sympathetic media coverage on refugee issues creates a higher awareness by the Dutch society, which, in turn, stimulates organizations to get more positively involved in refugees' inclusion. As one expert told us:

Media is representation. And we also noticed that we were called so much more by organizations all of a sudden. Two years ago it was silent, but now the phone keeps ringing. [...] I think we can only look at it in a positive way. It is a good tendency. (Expert 5)

Refugees' inclusion at work 
CDI 25,1

More precisely, in order to meet societal expectations (Carroll, 1999) that are partly fueled by the media, organizations implement CSR programs that focus on the inclusion of refugees at work:

What we notice is that more and more companies are more open to take social responsibility. If you look at companies that take initiatives and also provide places such as internship places or general working places, providing help in this way becomes more and more popular. So it gets more societal support. That definitely helps. (Expert 2)

Our second example captures the interplay between refugees' human capital (individual level) and biased processes in public organizations (organizational level). More specifically, one expert reported that most local governments are accustomed to bringing people with limited education into jobs, whereas they are not prepared to handle well-qualified refugees:

We have a lot of diversity. The local government is not designed or equipped to cope with the middle and higher segment of the status holders, apart from the diplomas, qualifications and language skills. In brief, this kind of individual treatment is very complex. (Expert 4)

Hence, especially refugees with higher education suffer from underemployment. Indeed, the highly educated refugees in our sample (i.e. those with university degrees) struggled because they could not continue their actual profession in the Netherlands, causing them to feel excluded from the Dutch labor market. Some of them expressed that they felt limited in the use of their potential, and that they "could do much more" (Refugee 2). Others phrased this more positively, describing their current position as "an opportunity to grow" (Refugee 4). In contrast, when asked if their qualifications fit their current position, the refugees with more limited levels of education (with high school-level degrees) expressed contentment with their jobs. This discrepancy between the experiences of refugees with higher and more limited levels of education is partly due to the local governments that are well prepared in getting the less educated into jobs, while being unprepared to do this task in the higher segments of the labor market.

A final example of how elements at different levels relate to each other demonstrates the dynamics between the individual and the country level. Multiple respondents mentioned that refugees' high motivation (individual level) can be a major facilitator for their inclusion at work. At the same time, we identified the legislative hurdles that many refugees face upon arriving in the Netherlands as a major barrier (country level) that negatively affects refugees' motivation (individual level) and eventually their exclusion from work. As summarized by an advisor for refugees at a local government:

[...] they will be in the [asylum] center for a relatively long period without being able to develop themselves or keep up with their potential [...] the drive they had is mostly gone [...] this is one of the unique distinctions they have, but the way we organize it here in The Netherlands makes that [unique distinction] disappear. (Expert 4)

This perception was shared across experts and refugees. In fact, one refugee told us:

You do not come to another country to sit, to receive something, the minimal, you just want to participate. People lose their motivation if you as a local government apply certain policy rules or not. (Refugee 4)

\section{Discussion}

This study provides an analysis of how individual, organizational and country influences and the interplay between them shape refugees' inclusion and exclusion in Dutch workplaces. We found several elements to be critical for refugees' inclusion. Specifically, we identified human capital at the individual level, strict language requirements as well as stereotypes and biased procedures at the organizational level, and economic crisis and legislative hurdles at the country level as barriers of refugees' inclusion in 
Dutch workplaces. Facilitators of refugees' inclusion are: host country language proficiency, social capital, volunteer work and motivation at the individual level, CSR and strategic use of the "refugee" label at the organizational level, and memory of the host country's migration history as well as sympathetic media coverage at the national level.

Most importantly, we presented three prominent examples of how these elements work together across the three levels, illustrating facilitating dynamics (e.g. sympathetic media coverage stimulates organizational CSR programs) as well as interplay with negative consequences for refugees' inclusion (e.g. biased procedures in local governments provoke well-qualified refugees' underemployment). Taken together, the interplay between the different levels described by our participants indicates a top-down flow of influence and indirect consequences of country-level barriers and facilitators on inclusion. For example, it is not the sympathetic media coverage itself that shapes refugees' inclusion but it may motivate organizational CSR programs with a more immediate impact on refugees' inclusion. Further, our empirical material did not indicate any "bottom-up effects," such that, for example, refugees would shape organizational inclusion practices. Although previous research has shown impactful agency by minority employees (e.g. Zanoni and Janssens, 2007) and institutional change by organizational actors (Battilana et al., 2009), we thus did not find any evidence for these bottom-up capacities to maneuver when it comes to refugees' inclusion.

By revealing the interplay between the different levels, we show that multi-level conceptualizations and the incorporation of the organizational level are essential for a comprehensive understanding of refugees' inclusion. Further, our relational framework on refugees' inclusion (Figure 2) extends earlier theorizing on diversity and inclusion by putting inclusion back in its broader context. The relational framework of diversity management (Syed and Özbilgin, 2009) has proven to be particularly valuable for interpreting our findings as its application has revealed that, in their quest for inclusion at work, refugees face unique facilitators and barriers at all three levels (individual, organizational and national) as well as the interplay between these levels. However, our findings indicate that the interplay tends to be characterized by a top-down flow and that, in coherence with Shore et al.'s (2011) conceptualization of inclusion on the intersection between the individual and his/her work unit, country-level influences tend to have indirect effects on refugees' inclusion.

Further, this study's findings inform ongoing discussions and advance recent research findings regarding refugees' inclusion at work. More specifically, our findings on the underemployment of well-qualified refugees mirror earlier discussions about the skill paradox, which describes the phenomenon that "the more immigrants are skilled and qualified, the less likely they are to find employment relative to their local counterparts" (Dietz et al., 2015, p. 1318). Yet, whereas previous studies assume recruiters' bias lies at the core of this phenomenon, this study sheds light on the role of local governments in brokering work for highly skilled and/or qualified refugees. This, in turn, underlines our study's contribution to context-specific perspectives on diversity and inclusion (Farndale et al., 2015; Klarsfeld et al., 2016; Nishii and Özbilgin, 2007). And yet in another important advancement of recent research, our finding regarding the negative influence of legislative hurdles on refugees' motivation offers a possible explanation for the causal relationship between waiting times in the asylum process and reduced employment rates of refugee status holders (Engbersen et al., 2015; Hainmueller et al., 2016).

Finally, emphasizing the thematic and logical connections between diversity management and refugees studies (de Jong, 2016), our study demonstrates that refugees' inclusion at work can be explained and investigated by drawing on a more general diversity management framework. Hence, an important implication is that refugees should be recognized as a distinctive group that requires special study, attention and protection (like women, ethnic minorities, people with a disability, etc.).

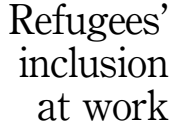


CDI

25,1

\section{Limitations and future research}

The main limitations of this study are its small sample size and a potential language barrier for those cases where the mother tongue of the respondent was neither Dutch nor English (the only spoken languages by the researchers), but Arabic, Armenian or French. Yet, the level of Dutch or English still had to be perceived as sufficient by the interviewer in order for the interview to be included in the sample. More generally, as a cross-cultural research team, we discussed inconclusive interview sections intensively to develop a clear understanding (Welch and Piekkari, 2006).

We have touched upon differences in barriers and facilitators of refugees' inclusion between refugees with higher and more limited levels of education, whereas previous studies have shown that refugees' inclusion at work can also be affected by the refugee's gender (Knappert et al., 2018; Tomlinson, 2010). We therefore recommend future research with larger samples to shed more light on differences between refugees (e.g. class and gender but also age, ethnicity/race, sexual orientation, etc.) to develop a deeper understanding of how intersectionalities (Crenshaw, 1991) may shape individual experiences of inclusion at work.

As our study provides rare insights on organizational influences on refugees' inclusion, we see the study of these initial starting points as particularly worthwhile to pursue in future research. For example, the theme of labeling refugees, depending on their status in the organization (candidate or employee) and organizational goals (to attract attention or not), extends previous academic knowledge and requires further investigations, for which we see previous work on diversity management and stigma (McLaughlin et al., 2004; Olsen and Martins, 2012) as useful point for departure. Furthermore, we recommend researchers to examine employers' efforts to recruit refugees in order to develop knowledge on facilitators and hindrances during that hiring process from the employers' perspective.

Whereas our results underline the importance of contextualizing refugees' inclusion and analyzing the influence of national peculiarities, we would like to inspire other researchers to apply our research design across countries to develop comparative studies to advance our knowledge of country differences and their influence on refugees' inclusion (Klarsfeld et al., 2016). Comparative studies are needed to further develop and test the influences identified in this study. For example, future research could investigate whether, how and to what extent media coverage affects the relationship between organizational programs and refugees' inclusion.

Regardless of the main level that researchers focus on, we have shown that a coherent understanding of refugees' inclusion necessitates the consideration of all three levels (individual, organizational and national). Our study may therefore encourage researchers to deepen and refine the concepts and dynamics we have identified in this paper. We recommend researchers deliver more empirical insights into the interplay between levels and the potential occurrence of bottom-up effects (Battilana et al., 2009; Zanoni and Janssens, 2007). For instance, we see refugees' agency and capacity to micro-emancipate (i.e. their actions to increase their control over their work arrangements) in host country organizations as a valuable research endeavor. Further, researchers could specify how organizational CSR or diversity programs that consider refugees next to other identity groups impact refugees' individual experiences and careers.

\section{Practical implications}

Given the results of this study, we call for a coordinated, collective effort to address the here identified barriers and facilitators. One factor that could help mobilizing such a collective effort is highlighting refugees as a special group and giving them similar attention and protection as other identity groups in society in general and in organizations in particular. 
Beside this collective effort, we see several implications for the relevant actors. First, for refugees it was recommended by all informants to learn the host society's language (cf. Ager and Strang, 2008). Additionally, finding volunteer work as soon as possible may be a promising route into employment. Second, we recommend employers introduce refugees to the Dutch workforce by providing volunteer and internship places (e.g. as part of their CSR programs). These programs should ideally be linked to opportunities for paid employment in order to avoid false hopes and exploitation. Moreover, since refugees are subject to negative stereotypes, we recommend employers provide diversity programs to decrease the likelihood of biased procedures and the prejudiced way employers and employees may look at refugees. Another implication for organizations is to carefully consider when to label people as "refugees." For example, as our findings show, hiring refugees as part of CSR programs most likely requires the use of the refugee label while recruiting, whereas using the same label might backfire once they are in the selection process or when they are employed. Third, we recommend policy makers to attend to the legislative hurdles. Most importantly, more resources are needed to speed up the currently demotivating registration processes. Further, the number of relocations that refugees have to endure should be minimized, to allow for their local integration. And finally, clear regulations and trainings of government employees could help to ensure fair and transparent procedures across the Netherlands.

\section{Conclusion}

The influx of refugees may be understood as a temporary phenomenon until the situation in the home country improves, but the number of refugees tragically is at an all-time high (UNHCR, 2018) and history shows that many refugees remain in their host societies (cf. Engbersen, 2015). Given the critical role of their economic integration, this study explores refugees' inclusion in Dutch workplaces. Based on our findings from interviews with refugees, employers and experts, we develop a relational framework of refugees' inclusion that contextualizes refugees' inclusion, specifies the interplay between levels, sheds light on the understudied employers' perspectives and thereby facilitates a comprehensive understanding of refugees' inclusion. Further, our context-sensitive analysis contributes to the growing body of country-specific perspectives on diversity and inclusion and provides several starting points for future research. Most importantly, we call for a collective effort to give refugees similar attention and protection as other identity groups, inside and outside of the Netherlands.

\section{References}

Ager, A. and Strang, A. (2008), "Understanding integration: a conceptual framework", Journal of Refugee Studies, Vol. 21 No. 2, pp. 166-191, doi: 10.1093/jrs/fen016.

Baranik, L.E., Hurst, C.S. and Eby, L.T. (2017), "The stigma of being a refugee: a mixed-method study of refugees' experiences of vocational stress", Journal of Vocational Behavior, Vol. 105, April, pp. 116-130, doi: 10.1016/j.jvb.2017.09.006.

Battilana, J., Leca, B. and Boxenbaum, E. (2009), "How actors change institutions: towards a theory of institutional entrepreneurship", Academy of Management Annals, Vol. 3 No. 1, pp. 65-107, doi: $10.5465 / 19416520903053598$.

Betts, A. and Collier, P. (2015), "Help refugees help themselves: let displaced Syrians join the labor market”, Foreign Affairs, Vol. 94, November/December, pp. 84-92.

Bleijenbergh, I.L., van Engen, M.L., van Terlouw, A. and Schalk, R. (2014), "Laws, policies and practices of diversity management in the Netherlands revisited", in Ng, E., Roper, I. and Tatli, A. (Eds), International Handbook on Diversity Management at Work, Edward Elgar Publishing, Cheltenham, pp. 162-174. 
CDI

25,1

Braun, V. and Clarke, V. (2006), "Using thematic analysis in psychology", Qualitative Research in Psychology, Vol. 3 No. 2, pp. 77-101, doi: 10.1191/1478088706qp063oa.

Carroll, A.B. (1999), "Corporate social responsibility: evolution of a definitional construct", Business \& Society, Vol. 38 No. 3, pp. 268-295, doi: 10.1177/000765039903800303.

Cheung, S.Y. and Phillimore, J. (2014), "Refugees, social capital, and labour market integration in the UK”, Sociology, Vol. 48 No. 3, pp. 518-536, doi: 10.1177/0038038513491467.

Cox, T. (1994), Cultural Diversity in Organizations: Theory, Research and Practice, Berrett-Koehler Publishers, San Francisco.

Crenshaw, K. (1991), "Mapping the margins: intersectionality, identity politics, and violence against women of color", Stanford Law Review, Vol. 43, July, pp. 1241-1299, doi: 10.2307/1229039.

de Jong, S. (2016), "Converging logics? Managing migration and managing diversity", Journal of Ethnic and Migration Studies, Vol. 42 No. 3, pp. 341-358, doi: 10.1080/1369183X.2015.1074857.

Derous, E., Ryan, A.M. and Nguyen, H.-H.D. (2012), "Multiple categorization in resume screening: examining effects on hiring discrimination against Arab applicants in field and lab settings", Journal of Organizational Behavior, Vol. 33 No. 4, pp. 544-570, doi: 10.1002/job.769.

de Vroome, T. and van Tubergen, F. (2010), "The employment experience of refugees in the Netherlands", International Migration Review, Vol. 44 No. 2, pp. 376-403, doi: 10.1111/ j.1747-7379.2010.00810.x.

Dietz, J., Joshi, C., Esses, V.M., Hamilton, L.K. and Gabarrot, F. (2015), "The skill paradox: explaining and reducing employment discrimination against skilled immigrants", International Journal of Human Resource Management, Vol. 10 No. 10, pp. 1318-1334, doi: 10.1080/09585192.2014.990398.

Dobbin, F. and Kalev, A. (2016), "Why diversity programs fail", Harvard Business Review, Vol. 94, July-August, pp. 52-60.

Ely, R.J. and Thomas, D.A. (2001), "Cultural diversity at work: the effects of diversity perspectives on work group processes and outcomes", Administrative Science Quarterly, Vol. 46 No. 2, pp. 229-273, doi: $10.2307 / 2667087$.

Engbersen, G. (2015), "Geen tijd te verliezen: van opvang naar integratie van asielmigranten Persbericht”, available at: www.wrr.nl/publicaties/persberichten/2015/12/16/geen-tijd-teverliezen-van-opvang-naar-integratie-van-asielmigranten (accessed January 30, 2018).

Engbersen, G.B.M., Dagevos, J., Jennissen, R.P.W., Bakker, L. and Leerkes, A.S. (2015), Geen tijd verliezen: van opvang naar integratie van asielmigranten, WRR, Den Haag.

Eurostat (2017), “Asylum quarterly report - statistics explained”, available at: http://ec.europa.eu/ eurostat/statistics-explained/index.php/Asylum_quarterly_report (accessed January 30, 2018).

Farndale, E., Biron, M., Briscoe, D.R. and Raghuram, S. (2015), "A global perspective on diversity and inclusion in work organisations", International Journal of Human Resource Management, Vol. 26 No. 6, pp. 677-687, doi: 10.1080/09585192.2014.991511.

García-Ramírez, M., de la Mata, M.L., Paloma, V. and Hernández-Plaza, S. (2011), "A liberation psychology approach to acculturative integration of migrant populations", American Journal of Community Psychology, Vol. 47 Nos 1-2, pp. 86-97, doi: 10.1007/s10464-010-9372-3.

Gläser, J. and Laudel, G. (2013), "Life with and without coding: two methods for early-stage data analysis in qualitative research aiming at causal explanations", Forum Qualitative Social Research, Vol. 14 No. 2, available at: www.qualitative-research.net/index.php/fqs/article/view/ 1886 (accessed July 5, 2018).

Hainmueller, J., Hangartner, D. and Lawrence, D. (2016), "When lives are put on hold: lengthy asylum processes decrease employment among refugees", Science Advances, Vol. 2 No. 8.

Hartog, J. and Zorlu, A. (2009), "How important is homeland education for refugees' economic position in the Netherlands?", Journal of Population Economics, Vol. 22 No. 1, pp. 219-246.

Hooijer, G. and Picot, G. (2015), "European welfare states and migrant poverty: the institutional determinants of disadvantage", Comparative Political Studies, Vol. 48 No. 14, pp. 1879-1904, doi: 10.1177/0010414015597508. 
Klarsfeld, A., Booysen, L.A.E., Ng, E., Roper, I. and Tatli, A. (2014), Country Perspectives on Diversity and Equal Treatment, Edward Elgar Publishing, Cheltenham.

Klarsfeld, A., Ng, E., Booysen, L., Christiansen, C. and Kuvaas, B. (2016), "Comparative equality and diversity: main findings and research gaps", Cross Cultural \& Strategic Management, Vol. 23 No. 3, pp. 394-412, doi: 10.1108/CCSM-03-2016-0083.

Knappert, L., Kornau, A. and Figengül, M. (2018), "Refugees' exclusion at work and the intersection with gender: insights from the Turkish-Syrian border”, Journal of Vocational Behavior, Vol. 105, April, pp. 62-82, doi: 10.1016/j.jvb.2017.11.002.

Krahn, H., Derwing, T., Mulder, M. and Wilkinson, L. (2000), "Educated and underemployed: refugee integration into the Canadian labour market", Journal of International Migration and Integration, Vol. 1 No. 1, pp. 59-84, doi: 10.1007/s12134-000-1008-2.

Lindgreen, A. and Swaen, V. (2010), "Corporate social responsibility", International Journal of Management Reviews, Vol. 12 No. 1, pp. 1-7, doi: 10.1111/j.1468-2370.2009.00277.x.

McLaughlin, M.E., Bell, M.P. and Stringer, D.Y. (2004), "Stigma and acceptance of persons with disabilities: understudied aspects of workforce diversity", Group \& Organization Management, Vol. 29 No. 3, pp. 302-333, doi: 10.1177/1059601103257410.

Markaki, Y. and Longhi, S. (2013), "What determines attitudes to immigration in European countries? An analysis at the regional level”, Migration Studies, Vol. 1 No. 3, pp. 311-337, doi: 10.1093/ migration/mnt015.

MIPEX (2018), “NetherlandsIMIPEX 2015”, available at: www.mipex.eu/netherlands (accessed January $30,2018)$.

Nishii, L.H. (2013), "The benefits of climate for inclusion for gender-diverse groups", Academy of Management Journal, Vol. 56 No. 6, pp. 1754-1774, doi: 10.5465/amj.2009.0823.

Nishii, L.H. and Özbilgin, M.F. (2007), "Global diversity management: towards a conceptual framework", International Journal of Human Resource Management, Vol. 18 No. 11, pp. 1883-1894, doi: 10.1080/ 09585190701638077.

Olsen, J.E. and Martins, L.L. (2012), "Understanding organizational diversity management programs: a theoretical framework and directions for future research", Journal of Organizational Behavior, Vol. 33 No. 8, pp. 1168-1187, doi: 10.1002/job.1792.

Pedersen, M.H. (2012), "Going on a class journey: the inclusion and exclusion of Iraqi refugees in Denmark", Journal of Ethnic \& Migration Studies, Vol. 38 No. 7, pp. 1101-1117, doi: 10.1080/ 1369183X.2012.681453.

Peretz, H., Levi, A. and Fried, Y. (2015), "Organizational diversity programs across cultures: effects on absenteeism, turnover, performance and innovation”, International Journal of Human Resource Management, Vol. 26 No. 6, pp. 875-903, doi: 10.1080/09585192.2014.991344.

Portes, A. (2000), "The two meanings of social capital", Sociological Forum, Vol. 15 No. 1, pp. 1-12.

Portes, J. (2018), "Immigration is good for economic growth. If Europe gets it right, refugees can be too", HuffPost, available at: www.huffingtonpost.com/jonathan-portes/economic-europe-refugees_b_ 8128288.html (accessed January 30, 2018).

Razenberg, I. and de Gruijter, M. (2017), Hoe kunnen gemeenten werkgevers ondersteunen bij het aannemen van vluchtelingen?, Kennisplatform Integratie \& Samenleving, Utrecht.

Rijksoverheid (2018a), "Hoeveel geld krijgen asielzoekers in Nederland?", available at: www. rijksoverheid.nl/onderwerpen/asielbeleid/vraag-en-antwoord/hoeveel-geld-krijgen-asielzoekersin-nederland (accessed November 10, 2018).

Rijksoverheid (2018b), "Kamerbrief: Verdere integratie op de arbeidsmarkt: De economie heeft iedereen nodig!", available at: www.rijksoverheid.nl/documenten/kamerstukken/2018/03/30/kamerbriefverdere-integratie-op-de-arbeidsmarkt-de-economie-heeft-iedereen-nodig (accessed November 10, 2018).

SER (2018), Vluchtelingen en werk: Een nieuwe tussenbalans, Sociaal Economische Raad, Den Haag. 
CDI

Syed, J. and Pio, E. (2010), "Veiled diversity? Workplace experiences of Muslim women in Australia", Asia Pacific Journal of Management, Vol. 27 No. 1, pp. 115-137, available at: http://dx.doi.org/ 10.1007/s10490-009-9168-x

The Economist (2015), "Getting the new arrivals to work", The Economist, December 15.

The Economist (2016), "Why the EU-Turkey deal is controversial”, The Economist, April 11.

Tomlinson, F. (2010), "Marking difference and negotiating belonging: refugee women, volunteering and employment", Gender, Work \& Organization, Vol. 17 No. 3, pp. 278-296, doi: 10.1111/ j.1468-0432.2008.00399.x.

UNHCR (2018), "Flowing across borders", available at: www.unhcr.org/refugees.html (accessed January 15, 2018).

van Wassenhove, L.N. (2015), "What's Europe's long-term plan for integrating refugees?", Harvard Business Review, available at: https://hbr.org/2015/09/whats-europes-long-term-plan-forintegrating-refugees (accessed January 15, 2018).

VluchtelingenWerk (2018), "Vluchtelingen in getallen", available at: www.vluchtelingenwerk.n1/sites/ public/u10237/Vluchtelingen $\% 20$ in $\% 20$ getallen $\% 202018 \%$ 20definitief $\% 20 \mathrm{klikbare} \% 20$ inhoudsopgave\%2029072018.pdf (accessed November 9, 2018).

Welch, C. and Piekkari, R. (2006), "Crossing language boundaries: qualitative interviewing in international business", Management International Review, Vol. 46 No. 4, pp. 417-437, doi: 10.1007/s11575-006-0099-1.

Yakushko, O., Backhaus, A., Watson, M., Ngaruiya, K. and Gonzalez, J. (2008), "Career development concerns of recent immigrants and refugees", Journal of Career Development, Vol. 34 No. 4, pp. 362-396, doi: $10.1177 / 0894845308316292$.

Zanoni, P. and Janssens, M. (2007), "Minority employees engaging with (diversity) management: an analysis of control, agency, and micro-emancipation”, Journal of Management Studies, Vol. 44 No. 8, pp. 1371-1397, doi: 10.1111/j.1467-6486.2007.00700.x.

Zikic, J., Bonache, J. and Cerdin, J.-L. (2010), "Crossing national boundaries: a typology of qualified immigrants' career orientations", Journal of Organizational Behavior, Vol. 31 No. 5, pp. 667-686, doi: $10.1002 /$ job.705.

\section{Corresponding author}

Hans van Dijk can be contacted at: J.vandijk1@uvt.nl

For instructions on how to order reprints of this article, please visit our website:

www.emeraldgrouppublishing.com/licensing/reprints.htm

Or contact us for further details: permissions@emeraldinsight.com 